\title{
OPTIMALISASI PENGEMBANGAN EKONOMI LOKAL (PEL) BERBASIS SUMBER DAYA LAUT PERIKANAN DI DESA MALAKA, KECAMATAN PEMENANG MELALUI EDUKASI DAN PENDAMPINGAN PENGOLAHAN IKAN HASIL TANGKAPAN NELAYAN
}

\author{
Aulia Febry Afiyani ${ }^{1 *}$, Dewi Ulandari ${ }^{2}$, Gusti Ati ${ }^{*}$, Hibban Kholiq ${ }^{4}$, Hidayatussalihin ${ }^{5}$, Maulana \\ Akbar $^{6}$, Muhammad Habiburrahman ${ }^{7}$, Nadya Septira ${ }^{8}$, Royanurbayani ${ }^{9}$, Yuni Mardiana ${ }^{10}$ \\ ${ }^{1}$ Pendidikan Akuntansi, Fakultas Ekonomi dan Bisnis, Universitas Mataram \\ 2Pendidikan Agroteknologi, Fakultas Pertanian, Universitas Mataram, Mataram \\ ${ }^{3}$ Pendidikan Sosiologi, Fakultas Keguruan dan IImu Pendidikan, Universitas Mataram \\ ${ }^{4}$ Pendidikan Matematika, Fakultas Matematika dan IImu Pengetahuan Alam, Universitas Mataram \\ ${ }^{5}$ Pendidikan Peternakan, Fakultas Peternakan, Universitas Mataram, Mataram \\ ${ }^{6}$ Pendidikan Peternakan, Fakultas Peternakan, Universitas Mataram, Mataram \\ ${ }^{7}$ Pendidikan IImu Hukum, Fakultas Hukum, Universitas Mataram, Mataram \\ ${ }^{8}$ Pendidikan Hubungan Internasional, Fakultas, Universitas Mataram, Mataram \\ 9Pendidikan IImu Tehnik Pangan, Fakultas Tehnik Pangan, Universitas Mataram, Mataram, \\ ${ }^{10}$ Pendidikan Peternakan, Fakultas Peternakan, Universitas Mataram, Mataram,
} *Co-Author :febryaulia17@gmail.com

\begin{abstract}
ABSTRAK. Desa Malaka, Kecamatan Pemenang, merupakan salah satu desa yang penduduknya sebagian besar bekerja sebagai nelayan di Kabupaten Lombok Utara. Kendala yang dihadapi oleh masyarakat adalah hasil tangkapan yang diperoleh nelayan dijual pada tengkulak dengan harga murah. Alternatif solusi yang dapat dilakukan untuk mengatasi kendala tersebut adalah dengan mengadakan edukasi dan pendampingan pengolahan ikan hasil tangkapan nelayan. Tujuan dari program ini adalah memberikan edukasi kepada masyarakan Desa Malaka dan melakukan pendampingan pengolahan ikan hasil tangkapan nelayan menjadi abon ikan. Metode yang digunakan adalah persiapan program, sosialisasi dan pelatihan, pembuatan produk, pemanfaatan, monitoring, dan mengevaluasi. Hasil dari program tersebut adalah kelompok pengolahan dan pemasaran yang berpotensi menghasilkan abon ikan tongkol Malaka atau meningkatkan nilai jual produk sehingga masyarakat dapat memproduksi hasil olahan sumber daya laut yang memiliki nilai ekonomi tinggi untuk meningkatkan perekonomian masyarakat.
\end{abstract}

Kata Kunci: Nelayan, Ikan Tongkol, Abon

\begin{abstract}
.
Malaka Village, Pemenang Subdistrict, is one of the villages whose residents mostly work as fishermen in North Lombok Regency. Constraints faced by the community are the catches obtained by fishermen sold to wholesaler in low prices. An alternative solution that can be done to overcome these obstacles is to conduct education and assistance in processing fish caught by fishermen. The aim of this program is to provide education to the people of Malaka Village and provide assistance in processing fish caught by fishermen into shredded fish. The methods used are program preparation, socialization and training, product making, utilization, monitoring, and evaluating. The results of the program are processing and marketing groups that have the potential to produce Abon Tongkol Malaka or increase the sale value of products so that the community can produce processed marine resources that have a high economic value to improve the economy of the community.
\end{abstract}

Keyword: Fishermen, Tongkol Fish, Abon. 


\section{PENDAHULUAN}

Abon merupakan produk kering, dimana penggorengan merupakan salah satu tahap yang umumnya dilakukan dalam pengolahannya (Fachrudin, 1997). Lama penggorengan dilakukan anatar 30-60 menit atau tergantunng bahan yang digoreng (Wibowo dan Paraninangin, 2004). Ikan adalah salah satu bahan makanan yang digemari dan di konsumsi oleh sebagian besar masyarakat. Secara umum ikan cepat mengalami pembusukan sehingga dibutuhkan teknologi pengawetan ikan ataupun olahan ikan sebagai upaya untuk memperpanjang umur simpannya, diantaranya inovasi pengolahan ikan menjadi abon ikan (Kusumayanti et al 2011).

Ikan tongkol atau (Euthynnus affinis C.) adalah ikan yang memiliki nilai gizi yang berpotensi cukup tinggi serta memiliki nilai ekonomis tinggi. Ikan tongkol memiliki kandungan protein yang tinggi yaitu 26,2 mg/100 gr dan sangat cocok dikonsumsi oleh anak-anak dalam masa pertumbuhan, selain itu ikan tongkol juga sangat kaya akan kandungan asam lemak omega 3. Komponen kimia utama daging ikan tongkol adalah air, prorein, dan lemak yaitu berkisar 98\% dari total berat daging. Komponen ini berpengaruh besar terhadap nilai nutrisi, sifat fungsi, kualitas sensori dan stabilitas penyimpanan daging. Kandungan komponen kimia lainnya seperti karbohidrat, vitamin dan mineral berkisar $2 \%$ yang berperan pada proses biokimia didalam jaringan ikan. Oleh karena itu, ikan dan hasil produknya banyak dimanfaatkan oleh orang-orang yang mengalami kesulitan pencernaan sebab mudah dicerna (Sikorski, 2010).

Abon ikan merupakan salah satu alternative pengelolaan hasil perikanan yang tidak asing lagi kita dengar. Hampir semua orang pernah dan suka memakannya atau dapat membuatnya, karena abon dikenal dengan rasa yang enak, bisa sebagai lauk seta proses pembuatannya mudah.

Abon ikan adalah hasil olahan yang berwujud gumpalan-gumpalan serat daging yang halus dan kering. Bahan baku abon biasanya dibuat dari daging sapi, daging ayam, daging domba. Abon ikan juga salah satu produk olahan perikanan yang terbuat dari daging ikan dan diberi bumbu-bumbu sebagai penambah cita rasa. Produk yang dihasilkan mempunyai tekstur yang lembut, rasa enak, aroma yang khas, dan mempunyai daya simpan yang relative lama. Abon ikan merupakan produk kering dimana penggorengan merupakan salah satu tahap yang dilakukan dalam pengolahannya, selian itu jenis ikan yang diolah menjadi abon umumnya adalah ikan laut jenis pelagis seperti tongkol, tenggiri, tuna, cakalang dan lain-lain (Suryani, 2007).

Abon ikan tongkol merupakan salah satu ikan yang termasuk ikan air asin. Untuk mendapatkan ikan tongkol ini sangat mudah. Ikan tongkol ini sudah banyak dijual di pasar atau supermarket yang dijual dengan harga yang sangat terjangkau. Di Indonesia sendiri ikan tongkol ini banyak disukai oleh masyarakat. Selain harganya yang terjangkau, ikan tongkol ini juga sangat baik untuk kesehatan pada tubuh kita. Salah satu manfaat yang dimiliki oleh ikan tongkol ini adalah menyehatkan mata. Hal ini diungkap oleh seorang peneliti John Hopkins School of Medicine yang mengungkapkan bahwa ikan tongkol ini memiliki kandungan zat omega 3 dipercaya dapat mengurangi resiko mengalami AMD (Age Macular Disease) atau jenis penyakit mata karena faktor penuaan. Selain itu, kandungan omega 3 yang terdapat pada ikan tongkol ini juga dipercaya dapat menurunkan angka resiko mengalami kerusakan pada mata.

Karena ikan tongkol memiliki manfaat yang sangat baik untuk kesehatan pada tubuh, maka tidak heran banyak masyarakat yang menjadikan ikan tongkol ini untuk bahan pembuatan makanan. Salah satu olahan makanan yang terbuat dari ikan tongkol adalah abon ikan tongkol.

Abon ikan tongkol merupakan salah satu olahan makanan yang banyak difavoritkan oleh masyarakat mulai dari kalangan anak-anak hingga kalangan dewasa. Bagi masyarakat yang merasa bosan dengan abon daging mungkin abon ikan tongkol bisa menjadi pilihan. Olahan makanan abon ikan tongkol ini memiliki cita rasa enak dan juga gurih yang sangat cocok untuk dijadikan lauk pauk 
dan dinikmati bersama keluarga atau bersama rekan terdekat dan juga olahan ikan tongkol ini juga sangat cocok dikonsumsi oleh balita dicampur dengan bubur agar mudah dicerna. Abon ikan tongkol ini biasanya sifatnya kering bisa disimpan untuk beberapa waktu.

\section{ANALISIS PERMASALAHAN}

Hasil tangkapan nelayan di Desa Malaka berupa Ikan Tongkol yang melimpah merupakan sebuah peluang untuk meningkatkan perekonomian masyarakat desa. Program pengolahan merupakan sebuah kegiatan industri yakni mengolah bahan mentah, bahan baku, bahan setengah jadi menjadi produk yang siap dipasarkan dengan nilai jual yang lebih tinggi. Kegiatan Pemberdayaan Masyarakat dimulai dari merancang pelaksanaan program yang kemudian dilanjutkan dengan persiapan progran yang meliputi survei lokasi.

Hasil survei menujukan bahwa kendala yang dihadapi masyarakat Desa Malaka antara lain 1) Harga jual Ikan Tongkol yang kurang stabil bahkan relatif rendah, 2) Tidak adanya pengetahuan dalam hal pengolahan hasil tangkapan laut dengan nilai jual yang lebih tinggi , 3) Kurangnya kemampuan masyarakat dalam hal inovasi produk dengan nilai jual yang lebih tinggi. Tahap selanjutnya adalah persiapan instrumen monitoring dan evaluasi yaitu pengetahuan masyarakat yang meliputi cara mengolah ikan tongkol menjadi abon, mempersiapkan packaging produk sehingga dapat dipasarkan, serta mengurus perijinan setelah membuat sebuah produk, dan lainlain.

\section{SOLUSI YANG DITAWARKAN}

Penyuluhan dan Pelatihan Pembuatan Abon Tongkol Malaka "ATOM" dilakukan sebagai solusi untuk membantu para keluarga nelayan dan kelompok pengolah di Desa Malaka untuk mengolah hasil tangkapan sehingga dapat dijual dengan harga yang lebih tinggi. Penyuluhan pertama tentang cara mengolah Ikan Tongkol Menjadi Abon yang kemudian diberi nama "Abon Tongkol Malaka".

Kegiatan dilakukan pada tanggal 18 februari 2019 di Dusun Pandanan, Desa Malaka, Kecamatan Pemenang, Kabupaten Lombok Utara. Alat yang digunakan dalam program ini adalah kompor, wajan, sutil, blender, piring, mangkok, pisau, sarung tangan plastik, dan kemasan. Sedangkan bahan yang digunakan adalah ikan tongkol, cabai rawit merah, cabai merah besar, bawang merah, bawang putih, kemiri, santan, serai (sereh), lengkuas, kunyit, garam dan gula merah. Prosedur kerja pembuatan abon ikan tongkol adalah sebagai berikut :

1) Mempersiapkan alat dan bahan,

2) Menghaluskan ikan tongkol yang sudah dipindang dan dibersihkan tulangnya,

3) Blender semua bahan bumbu yang terdiri dari cabai rawit merah, cabai merah besar, bawang merah, bawang putih, kemiri, lengkuas, kunyit dan gula merah,

4) Panaskan wajan dengan api kecil, setelah panas masukkan bumbu yang sudah di blender atau dihaluskan kemudian masukkan santan, serai (sereh), dan garam,

5) Setelah bumbu sudah meletup-letup, masukkan ikan tongkol yang sudah dihaluskan, aduk sampai ikan tongkol tercampur rata dengan bumbu,

6) Aduk ikan tongkol sampai kering dengan api kecil,

7) Setelah abon ikan tongkol matang, diamkan beberapa menit untuk didinginkan

8) Mengemas abon ikan tongkol dalam kemasan yang sudah disediakan.

\section{Tahap 1}

Persiapan program.

\section{Tahap 2}

Sosialisasi tentang produk abon ikan tongkol. 


\section{Tahap 3}

Pelatihan pembuatan produk abon ikan tongkol.

\section{Tahap 4}

Pemasaran produk abon ikan tongkol.

Metode pengumpulan data pada program ini adalah dengan survei hasil tangkapan laut para nelayan dan pendataan istri para nelayan. Analisis data menggunakan deskriptif kualitatif.

\section{HASIL DAN PEMBAHASAN}

Program edukasi dan pendampingan pengolahan hasil laut di Dusun Pandanan, Desa Malaka dilakukan secara terstruktur dan melibatkan masyarakat secara langsung. Hasil tangkapan nelayan di Desa Malaka berupa Ikan Tongkol yang melimpah merupakan sebuah peluang untuk meningkatkan perekonomian masyarakat desa. Program pengolahan merupakan sebuah kegiatan industri yakni mengolah bahan mentah, bahan baku, bahan setengah jadi menjadi produk yang siap dipasarkan dengan nilai jual yang lebih tinggi.

Kegiatan Pemberdayaan Masyarakat dimulai dari merancang pelaksanaan program yang kemudian dilanjutkan dengan persiapan progran yang meliputi survei lokasi. Hasil survei menujukan bahwa kendala yang dihadapi masyarakat Desa Malaka antara lain 1) Harga jual Ikan Tongkol yang kurang stabil bahkan relative rendah, 2) Tidak adanya pengetahuan dalam hal pengolahan hasil tangkapan laut dengan nilai jual yang lebih tinggi ,3) Kurangnya kemampuan masyarakat dalam hal inovasi produk dengan nilai jual yang lebih tinggi. Tahap selanjutnya adalah persiapan instrumen monitoring dan evaluasi yaitu pengetahuan masyarakat yang meliputi cara mengolah ikan tongkol menjadi abon, mempersiapkan packaging produk sehingga dapat dipasarkan, serta mengurus perijinan setelah membuat sebuah produk, dan lain-lain.

Penyuluhan dan Pelatihan Pembuatan Abon Tongkol Malaka "ATOM" dilakukan sebagai solusi untuk membantu para keluarga nelayan dan kelompok pengolah di Desa Malaka untuk mengolah hasil tangkapan sehingga dapat dijual dengan harga yang lebih tinggi. Penyuluhan pertama tentang cara mengolah Ikan Tongkol Menjadi Abon yang kemudian diberi nama "Abon Tongkol Malaka".

Sosialisasi yang dilakukan dimulai dari cara memasak dan mengolah ikan mulai dari meracik bumbu hingga menjadi abon ikan yang siap untuk dimakan. Sosialisasi ini diharapkan dapat memberikan edukasi kepada masyarakat khususnya kelompok pengolah agar mampu mengolah ikan tongkol menjadi produk yang lezat dan laku di pasaran. Tahap selanjutnya ialah mempersiapkan packaging yang baik sehingga dapat diterima oleh konsumen. Tahap akhir dari proses sosialisasi ialah membantu masyarakat dalam hal mengurus perijinan didampingi oleh Penyuluh Perikanan Desa Malaka agar produk yang dipasarkan terjamin mutu serta kualitasnya. 


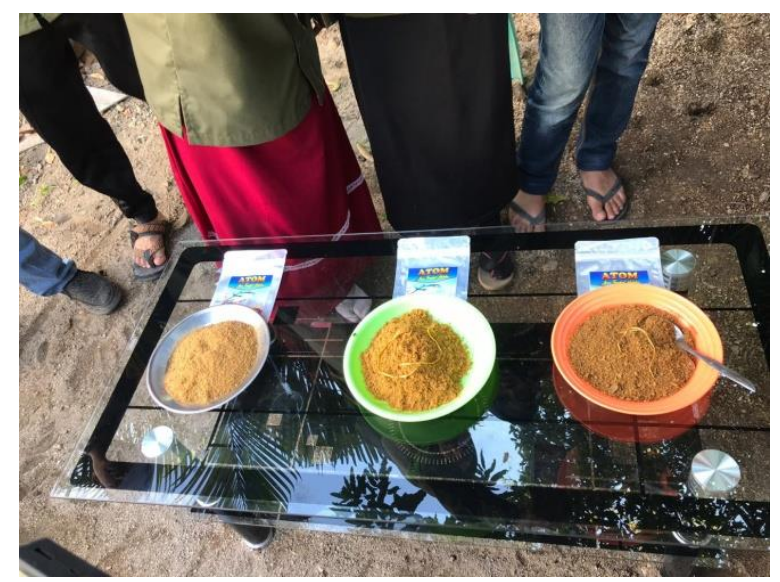

Gambar 1. Sosialisasi Pembuatan Abon Tongkol Malaka

Hasil produk yang dihasilkan oleh masyarakat kemudian siap dipasarkan di beberapa supermarket yang ada di Kabupaten Lombok Utara khususnya Kecamatan Pemenang seperti Zohri Mart, Warung Wakaf, BumDes Mart, dan beberapa tempat lainnya.

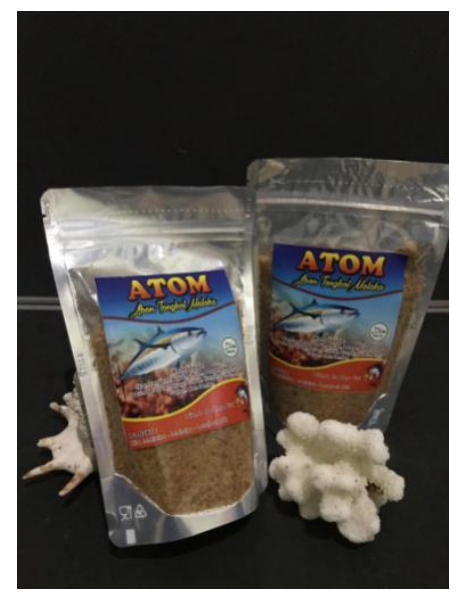

Gambar 2. Produk Abon Tongkol Malaka

\section{KESIMPULAN}

Program edukasi dan pelatihan pengolahan sumber daya laut berupa ikan tongkol menjadi Abon Tongkol Malaka di Desa Malaka adalah masyarakat khususnya kelompok pengolah perikanan mampu mengolah ikan tongkol menjadi Abon Tongkol Malaka untuk meningkatkan nilai jual produk dan mengembangkan perekonomian dengan berkegiatan industri. Masyarakat berkomitmen untuk terus berupaya menjalankan kegiatan agar dapat berkelanjutan.

\section{REFERENSI}

Anonim. 1997. SNI 01-3707-1995 Abon Ikan. Badan Standarisasi Nasional. Jakarta.

Arsyad, Loncolin. 1999. Pengantar Perencanaan dan Pembangunan Ekonomi Daerah Edisi 1. Yogyakarta: BPFE Yogyakarta.

Fachruddin, I., 1997. Membuat Abon Ikan. Kanisius. Yogyakarta. 
Fatmawati, F., Mtoharoh, S., Sara Y. et al. 2014. Makalah THP Tradisional Abon Ikan Tongkol. Universitas Brawijaya: Malang.

Khomsan, Ali. 2004. Peranan Pangan dan Gizi Untuk Kualitas Hidup. PT. Gramedia Widiasarana Indonesia. Jakarta.

Kusmayanti, Heny., Widi Astuti, Rtd. Wisnu Broto. 2011. Inovasi Pembuatan Abon Ikan Sebagai Salah Satu Teknologi Pengawetan Ikan. Gema Teknologi Vol. 16 No. 3. Universitas Negeri Semarang.

Nababan, Susy Suelestari, dkk. 2017. Pengaruh Perbedaan Jenis Daging terhadap Penerimaan Abon Cakalang (Katsuwonus pelamis).

Sikorski Zc, A Kalakowski \& B Pan. 2010. The Nutritive Composition Of The Major Groups Of Marine Food Organism. Di Dalam Z. E Sikorski (Ed.). Seafood : Resources, Nutritional Composition And Preservation. Florida: Crc Press Inc.

Wibowo, S. dan R. Peraninangin.2004. Pengolaham Abon Ikan. Badan Riset kelautan dan perikanan.departemen kelautan dan perikanan.

www.agrowindo.com/peluang-usaha-abon-ikan-tongkol-dan-analisa-usahanya.htm (diakses pada tanggal 27 Maret 2019 pukul 13.29 WITA.)

https://www.academia.edu/10566237/Industri adalah kegiatan ekonomi yang mengolah bahan mentah? auto=download (diakses pada tanggal 27 Maret 2019 pukul 13.29 WITA.) 